Beata Grochala

Uniwersytet tódzki

(D) https://orcid.org/0000-0002-3885-8964

\title{
Dialog a telewizyjna transmisja sportowa
}

\author{
Dialogue and TV Sports Broadcast
}

\begin{abstract}
The theme of the research is the spoken teut of sports television broadcasts, especially the conversational forms that dominate at modern television. The research material were selected broadcasts of various sports disciplines, which took place at September and October 2020. For several years in Polish sports television broadcasts is a new kind of commentary. It is conducted by two people - a journalist and an expert or journalist and journalist. In the article author considers the type of communication relations between this two people. Because in this situation are two people, the most natural form of communication is dialogue. However, research shows that journalist and expert communicate also another way, such as monologues. Commentator duets conduct a professional reporting and commentary dialogue, or their exchanges resemble the reactions of excited fans, or they use „parallel monologue” related to the conduct of separate narratives related thematically. In the article author describes and categorizes them.
\end{abstract}

Key words: dialogue, monologue, sports TV broadcast

Abstrakt: Przedmiotem badań artykułu jest tekst mówiony telewizyjnej transmisji sportowej, a zwłaszcza formy konwersacyjne, które dominują we współczesnym przekazie telewizyjnym. Z wybranych transmisji różnorodnych dyscyplin sportowych emitowanych we wrześniu i październiku 2020 r. wyekscerpowano materiał badawczy, który stanowi tekst komentarza prowadzonego przez dwie osoby - dziennikarza i eksperta bądź w konfiguracji dziennikarz-dziennikarz. W artykule rozpatrywany jest typ relacji komunikacyjnej pomiędzy nimi. Ponieważ mamy do czynienia z dwiema osobami, najbardziej naturalną formą wydaje się dialog. Jednak badania pokazują, że występują także inne formy komunikacyjne. Duety komentatorskie albo prowadzą profesjonalny dialog relacjonująco-komentatorski, albo ich wymiany przypominają reakcje rozemocjonowanych kibiców, albo pojawia się „monolog równoległy”, związany z prowadzeniem odrębnych narracji powiązanych tematycznie.

Słowa kluczowe: dialog, monolog, telewizyjna transmisja sportowa

Widowisko telewizyjne, skomplikowana siatka semiotyczna, to tekst, którego spójność realizuje się wielopłaszczyznowo. Łączy ono w sobie kod audialny (akustyczny) pod postacią melodii, dźwięków oraz słowa mówionego z kodem wizualnym (ikonicznym) pod postacią obrazu i słowa pisanego (LoEWE, 2013: 290). Dla niniejszych rozważań najważniejszym elementem jest słowo mówione, które $w$ przekazach telewizyjnych może przybierać różnorodną postać. Formy konwersacyjne dominujące we współczesnym przekazie telewizyjnym, nie są bowiem jednorodne. Co więcej, telewizja redefiniuje pewne zakorzenione $w$ teorii komunikacji pojęcia. W dalszej części tekstu zaprezentowano przemianę komentarza dziennikarsko-eksperckiego towarzyszącego telewizyjnej transmisji wydarzeń sportowych. 
Bazę materiałową stanowią wybrane transmisje różnych dyscyplin sportowych emitowane we wrześniu i październiku 2020 roku na antenach kilku stacji telewizyjnych (ogólnych i tematycznych). Czas emisji jest tu istotny ze względu na sytuację społeczno-epidemiczną. W marcu 2020 roku zawieszono wszystkie rozgrywki sportowe z powodu epidemii COVID-19. Od maja 2020 roku rozpoczęto stopniowe odmrażanie widowisk sportowych, ale bez udziału publiczności. Częściowy powrót do normalności nastąpił we wrześniu 2020 roku, jednak szybko okazało się, że był to stan chwilowy. Kibice, stęsknieni za sportem, z ogromnym zaangażowaniem śledzili zatem wszelkie transmisje sportowe nadawane przez rozmaite stacje telewizyjne. By zilustrować prezentowane w dalszej części tekstu teorie, wybrano transmisje z następujących dyscyplin: piłka siatkowa, piłka nożna, piłka ręczna, snooker, emitowane na antenie TVP, TVP Sport, Eleven Sports, Polsat Sport oraz Eurosport.

Zawarte $w$ tytule niniejszego artykułu słowo dialog towarzyszy refleksji humanistycznej od starożytności. Jego definicje, próby kategoryzacji zawarte zostały w licznych opracowaniach literaturoznawczych, językoznawczych, filozoficznych itp. (por. Warchala, 1991). Nie ma tu miejsca na prezentację wszystkich sposobów interpretacji owego pojęcia. Nie taki jest też cel badawczy. Jednak ze względu na porządek wywodu przyjęto słownikową definicję, zgodnie z którą dialog to „podstawowa forma istnienia, funkcjonowania języka mówionego; rozmowa; wypowiedzi co najmniej dwu osób - nadawcy i odbiorcy, których role $w$ dialogu naprzemiennie się wymieniają: ta sama osoba raz jest nadawcą, raz odbiorcą komunikatu [...]" (SKudrzykowa, Urban, 2000: 25). W dalszej części dialog traktowany jest jako pojęcie operacyjne, pewien punkt odniesienia wobec badanego materiału. Celem podjętym $w$ artykule jest bowiem próba ustalenia statusu tekstu stowarzyszonego z obrazem, stanowiącego komentarz do jakiegoś wydarzenia sportowego transmitowanego na żywo. Nie chodzi tu o opis genologiczny, ten został już dokonany (por. Grochala, 2016), lecz o przyjrzenie się językowi w swoistej interakcji.

Bazę materiałową stanowią wyimki z telewizyjnych transmisji sportowych z 2020 roku w zakresie różnych dyscyplin sportu, różnego poziomu rozgrywek, różnych stacji nadawczych itp. Przedstawione obserwacje będą ilustrowane najbardziej reprezentatywnymi lub ciekawymi przykładami i wówczas zostanie podana ich dokładna lokalizacja.

Aby dobrze ukazać prezentowane zagadnienie, warto odwołać się do pierwszych polskich badań nad dialogiem $w$ telewizji, które miały miejsce w latach 70. XX wieku w ośrodku krakowskim. Ich owocem były liczne publikacje dotyczące języka najnowocześniejszego $w$ owych czasach medium, w tym prace poświęcone właśnie dialogowi telewizyjnemu, jak również językowi transmisji sportowych. Za kluczowy dla prezentowanych tu treści należy uznać artykuł Dialog telewizyjny. Próba typologii autorstwa Bronisławy Ligary i Anny Rusowıcz (1979). Badaczki, kierując się rozstrzygnięciami Jana MuKA Řovskı́go (1970), uznały, że każda wypowiedź musi realizować się $w$ formie albo monologu, albo dialogu. Większość wypowiedzi telewizyjnych zakwalifikowały jako dialog, zastanawiając się jednocześnie, czy istnieje „odrębna, telewizyjna odmiana dialogu” (LıGARA, Rusowicz, 1979: 23). Za parametry wypowiedzi dialogowej uznały przede wszystkim udział dwóch rozmówców, adresowanie przekazu słownego do jednego z nich, przemienność ról nadawczo-odbiorczych. W toku dalszych analiz, nadal podążając tropem Mukařouskiego, Ligara i Rusowicz zdefiniowały dialog w telewizji jako „taki akt mowy, w którym: a) występują dwaj partnerzy rozmowy; b) przekaz jest skierowany do jednego, konkretnego uczestnika rozmowy [...]; role nadawcy 
i odbiorcy są wymienne" (LigArA, Rusowicz, 1979: 29). Autorki uznały, że najbardziej reprezentatywny dla sytuacji telewizyjnej jest dialog sytuacyjny, w którego obrębie wskazały na trzy pododmiany: a) dialog sytuacyjny bezpośredni - przedmiotem rozmowy jest sytuacja zewnętrzna; b) dialog sytuacyjny pośredni - zainspirowany sytuacją zewnętrzną, stanowi ona pretekst; c) dialog ze zneutralizowanym wpływem sytuacji zewnętrznej. Wśród gatunków, w których dominuje dialog, badaczki wskazały wywiad, dyskusję i rozmowę. Przywołane obserwacje zaprezentowano dość szczegółowo, albowiem, jak wspomniano, mają one charakter badań pionierskich nad dialogiem $w$ telewizji, mogą zatem stanowić punkt odniesienia dla analiz poczynionych współcześnie, a tym samym pokazać, jak zmieniła się telewizja.

Dla porządku naukowego wywodu należy wspomnieć jeszcze o jednej pracy dotyczącej bezpośrednio tematyki występujących $w$ telewizji różnych sposobów ukształtowania tekstu. Mowa o książce Katarzyny JACHıMowskıej (2005), w której autorka dokonuje podziału tekstów telewizyjnych na monolog, dialog i polilog. Pojawienie się kategorii polilogu jako najbardziej reprezentatywnej dla tekstów telewizyjnych badaczka argumentuje: a) częstą obecnością więcej niż dwóch osób w studiu telewizyjnym; b) bezpośrednim udziałem twórców w budowaniu napięcia polifonicznego; c) adresowaniem komunikatu do wielu aktywnych odbiorców; d) równoległością replik; e) nakładaniem się na siebie momentów zwrotnych; f) występowaniem operatorów metatekstowych, które przekształcają językowy przekaz jednokierunkowy i wielokierunkowy (por. JAcHıMowsKA, 2005: 27).

Ciekawe spostrzeżenia dotyczące medialnej mody na dialog zawarła $w$ swoim tekście Małgorzata KıTA (2004). Badaczka za Claudem HAGÈGEM (1985) traktuje dialog szeroko, tzn. „nie jako wyłącznie para: pytanie - odpowiedź, mimo wagi tego składnika, ale jako interlokucja w ogóle, wszelka interakcja językowa zachodząca bezpośrednio między dwiema osobami, będąca składnikiem definicyjnym gatunku ludzkiego" (HAGÈGE, 1985: 313, cyt. za KıтA, 2004: 172). Kita zwraca również uwagę na wpływ zmian technologicznych na kształt dialogu - dały one możliwość natychmiastowego kontaktu z odbiorcami, którzy mogą współtworzyć program, współuczestniczyć $w$ rozmowie, za pomocą rozmaitych mediów reagować na to, co dzieje się na antenie. „Programy i teksty oparte na formie dialogu, czyli mające strukturę wymiany, w której uczestnicy dysponują [...] możliwością stania się mówiącymi, wykorzystują różne jej formy, różne gatunki i odmiany gatunkowe" (KıTA, 2004: 172). To osadzenie $w$ gatunku staje się elementem spajającym, „jednoczącym tekst pod względem strukturalnym" (SzKUDLAREK-ŚMIECHOWICZ, 2010: 62). Co ważne, całościowy przekaz medialny nie składa się często tylko z tekstu dialogowego. Wielokrotnie oparty jest na mechanizmach rozmowy (sekwencje, wymiany, repliki), ale kontaminuje $w$ sobie także inne gatunki oparte na wymianie ról, jak wywiad, dyskusja itp. (por. SzkudLarek-Śmiechowicz, 2010: 63).

Przemiany, jakie dokonały się w obszarze mediów w XXI wieku, znajdują odzwierciedlenie także $w$ dyskursie telewizyjnym, co pokazały $w$ swoich publikacjach między innymi Iwona Loewe (2018) i Barbara Soвcza (2018). Ostatnia z wymienionych badaczek zwraca uwagę na to, że telewizji od lat udaje się wywoływać wrażenie rzeczywistości: „Specyficzna dla telewizji audiowizualność wyrażająca się w połączeniu mowy i ruchomego obrazu prowadzi do ukształtowania form komunikacji przypominających rozmowę między osobami prowadzącymi program telewizyjny i widzami i powstawania interakcji paraspołecznej. Ta 
z kolei zwiększa zaangażowanie emocjonalne widza w oglądany program i przywiązuje go do nadawcy" (Sовсzак, 2018: 99). Loewe podkreśla, że we współczesnej telewizji najczęściej stosowanym typem tekstu jest nie dialog, lecz polilog. Jak zaznacza, ,jego upowszechnienie zostało spowodowane wydaniami programów na żywo oraz brakiem ingerencji w wymiany między interlokutorami nawet $w$ sytuacji montażu programu i emitowania go z opóźnieniem" (LoEWE, 2018: 108). Odbiorca woli wymianę między interlokutorami, chce być jej uczestnikiem, choć bez pełnego prawa głosu, a symultaniczność przekazu daje mu taką możliwość. Ze względu na specyficzny tematycznie obszar dyskursu telewizyjnego, do którego odnosi się niniejszy artykuł, ważne jest spostrzeżenie Sobczak, która wskazuje na transmisję widowiska sportowego jako wydarzenie, które powinno być dla widza ciekawe, pasjonujące, wciągające. Tymczasem tak się często nie dzieje i mecz czy inne zawody są zwyczajnie nudne. Jednak na ekranie nie może być tego widać. „Zadaniem realizatora, wykorzystującego zabiegi dramatyzacji słowem, i obrazem [...], jest z tego surowca, jaki jest mu dostępny, stworzyć coś zajmującego" (Sовсzак, 2018: 142). Twórcy telewizyjnych transmisji sportowych szukają zatem cały czas nowych sposobów budowania przekazu telewizyjnego, by był on atrakcyjniejszy, ciekawszy, inny - słowem, by nie znudził się widzowi. Jednym ze środków temu służących jest zmienianie formuły tekstu stowarzyszonego z obrazem widowiska sportowego.

Opisana przez Kitę moda na dialog dotarła również do dziennikarstwa sportowego, a $w$ analizowanym tu zakresie - do telewizyjnych transmisji sportowych. Od kilkunastu lat obserwujemy zmianę modelu relacjonowania widowisk sportowych. W miejsce dziennikarza-komentatora pojawiają się duety - początkowo dziennikarsko-eksperckie, a dziś również dziennikarsko-dziennikarskie, których zadaniem jest opisywanie i komentowanie wydarzeń na arenie sportowej $w$ taki sposób, by zatrzymać jak najdłużej uwagę widza, zwłaszcza tego, który nie jest zagorzałym kibicem. Skoro mamy do czynienia z relacją prowadzoną przez dwie osoby, to wydawać by się mogło, że najczęstszą formą podawczą będzie dialog między nimi. Samemu modelowi „komentatorskiego dwugłosu” poświęcono osobny artykuł (por. Grochala, 2012), jednak od jego publikacji minęło już kilka lat i pewne kwestie uległy zmianom. Ponadto analizowany model komentowania stał się bardzo ekspansywny, co sprawia, że uznać go należy za podstawowy, a uważany do niedawna za powszechny schemat jednego komentatora relacjonującego wydarzenie sportowe ${ }^{1}$ - za typ występujący rzadko.

Refleksję poczynioną poniżej zainspirował również fakt, że trudno o jednoznaczną klasyfikację owych duugłosów komentatorskich. Andrzej Ostrowski twierdzi, że do zadań dziennikarza należy „budowanie dramaturgii związanej z przebiegiem transmitowanego widowiska, a ekspert wyraża swoje opinie związane ze sposobami, jakimi to widowisko przebiega" (Ostrowskı, 2007: 221-222). Jednak ten podział funkcji także ulega dziś coraz częściej zatarciu. Trzeba zatem zaktualizować wnioski z analiz opublikowanych w 2012 roku, iż „dziennikarz realizuje to, co klasycznie nazywane było relacją, a właściwie należałoby mówić o relacji z elementami komentarza. Natomiast ekspert to właśnie komentator, czyli osoba, która ocenia z perspektywy znawcy" (Grochala, 2012: 208). Dziś udział dwóch

${ }^{1}$ O takim typie relacji/komentarza pisał m.in. Jan Ożdżyński w publikacji Mówione warianty wypowiedzi w środowisku sportowym (1979), będącej, podobnie jak wspomniany wcześniej artykuł Ligary i Rusowicz, wynikiem badań nad językiem mówionym w telewizji. 
osób, które relacjonują i komentują wydarzenia sportowe, ma służyć przede wszystkim budowaniu atrakcyjności przekazu.

Jak wspomniano, pewien kłopot stanowi klasyfikacja formuły, w jakiej komunikują się z sobą osoby prowadzące transmisję. Pierwszy wybór to dialog - mamy bowiem do czynienia z dwiema osobami, które, ujmując rzecz w dużym uproszczeniu, naprzemiennie mówią o tym, co dzieje się na boisku czy innej arenie sportowej. Wyłączmy na razie z rozważań funkcję odbiorcy medialnego i skoncentrujmy się na samym sposobie komunikacji między komentatorami. Założenie, że prowadzą oni dialog, wydaje się jak najbardziej uzasadnione. Mamy bowiem do czynienia z wypowiedziami dwóch osób, które wymieniają się rolami nadawczo-odbiorczymi. Gdyby uznać te dwa parametry (obecność dwóch osób i wymienność ról nadawczo-odbiorczych) za jedyne wyznaczniki dialogu, to wówczas wszystkie analizowane tu wypowiedzi można by uznać za dialogowe, co więcej - za modelowe. Interlokutorzy nie wchodzą sobie w słowo, nie przerywają wypowiedzi, raczej nie dochodzi do ostrych wymian słownych o znamionach kłótni. Oto kilka typowo dialogowych wymian pochodzących z transmisji, w których wyraźnie zarysowuje się przemienność ról i widać odwołania do wypowiedzi poprzednika, choć nie zawsze są one formułowane wprost, lecz mają charakter kontekstowy, na przykład odnoszą się do danej akcji czy zawodnika:

D1: I to jest hat trick Polaka.

D2: I to jest jego 250 bramka dla Bayernu.

D1: Niemożliwy jest... (Eleven Sport, 4.10.2020) ${ }^{2}$.

D: Przypomnijmy, tutaj tylko trzy zmiany. Troszkę po macoszemu została potraktowana Liga Narodów.

E: Trzy zmiany i to jest chyba największy problem przy tylu zawodnikach powołanych na ten dwumecz [...] (TVP1, 4.09.2020).

D1: Jakie dobre to dotoczenie.

D2: Będzie musiał być dokładny. O’Sullivan.

D1: Będzie zagrywał na brązową (Eurosport, 24.09.2020).

Przywołane przykłady pokazują, że dialog opiera się nie tylko na samej wymienności ról. Ważne są również korespondujące z sobą w jakiś sposób wymiany (repliki), a te nie zawsze mają miejsce podczas transmisji. Oczywiście można założyć, że istnieje makrotemat wypowiedzi obu uczestników, jakim jest komentowane wydarzenie sportowe, a nawet szerzej - dana dyscyplina sportu. Jednak nawet wówczas należałoby $w$ formie dialogowej zawrzeć wskaźniki pozwalające, poza wymianą głosu osoby mówiącej, odnaleźć spójność tekstu dialogicznego. Tak się jednak nie dzieje. Często w duetach dziennikarsko-eksperckich mamy do czynienia z dwoma równoległymi, choć niewspółistniejącymi w czasie, monologami, tj. odrębnymi wypowiedziami zorganizowanymi wokół danego zagadnienia, przerywanymi wypowiedziami interlokutora. W celu lepszego zilustrowania tej tezy omówione zostanie bardziej szczegółowo kilka przykładów.

${ }^{2}$ Nie podaję tu nazwisk dziennikarzy ani ekspertów, gdyż nie są one istotne dla prowadzonego wywodu. Stosuję oznaczenia: D - dziennikarz, E - ekspert. 
Pierwsza wymiana pochodzi z meczu snookerowego komentowanego przez duet dziennikarzy. Jeden z nich koncentruje swoje wypowiedzi na zawodniku z Irlandii, Aaaronie Hillu, natomiast drugi - na graczu z Wielkiej Brytanii, Ronnie'm O’Sullivanie. Podczas pierwszych trzech wymian każdy z dziennikarzy prowadzi swój wątek. Dopiero początek czwartej wymiany to powrót do dialogu, pojawia się bowiem bezpośrednie nawiązanie do wypowiedzi poprzednika:

1. D1: To dobre zagranie Irlandczyka.

D2: Czytałem ostatnio wypowiedź O’Sullivana na temat jego treningów w czasie pandemii.

2. D1: Oj, chyba za blisko bandy ustawił białą.

D2: Ronnie twierdził, że był to dla niego bardzo cenny czas, nie miał problemów z izolacją. Jak mówił, stosuje ją często poza lockdownem.

3. D1: Niesamowite, Irlandczyk gra jakby to był jego setny turniej masters, a nie pierwszy w życiu.

D2: Na koniec wywiadu O'Sullivan odniósł się do braku publiczności podczas turniejów. Stwierdził, no jak myślisz, co stwierdził?

4. D1: Że chyba nie da rady pokonać tego młodego chłopaka z Irlandii (Eurosport, 24.09.2020).

W podobny sposób skonstruowana jest kolejna wymiana, tym razem z transmisji meczu piłki ręcznej między reprezentantkami Polski i Szwecji. Tu duet stanowią dziennikarz i ekspertka. Była zawodniczka koncentruje się na strategii ustawienia piłkarek szwedzkich w dwumeczu z naszymi zawodniczkami, natomiast dziennikarz relacjonuje bieżącą grę polskiej drużyny:

E: Szwedki były zadowolone z drugiej linii po tym pierwszym meczu. Linia obrony była dobra.

D: Jak się tutaj rozgrywa wszystko na naszą niekorzyść...

E: I Szwedki nie zmieniły niczego w swoim ustawieniu drugiej linii.

D: Trener dał zmianę, ale dziewczyny nie mogą się jakoś podnieść i tracą punkty, a nie powinny. Są dobrze rozegrane.

E: Szwedki są znane z konsekwencji $w$ tym swoim ustawieniu. Nawet jak coś nie zagra, to starają się nic nie zmieniać. Wychodzą z założenia, że każde ustawienie potrzebuje czasu na sprawdzenie.

D: Polki przy piłce, atak w kole... Tracimy okazję. Sędzia przerywa akcję (TVP Sport, 3.10.2020).

Także następny przykład to komentarz dziennikarza i eksperta. Tym razem dziennikarz odnosi się do rozgrywanych akcji, natomiast ekspert - do braku kibiców na stadionie spowodowanego epidemią koronawirusa:

D: Pierwsze trzy minuty spotkania. Holendrzy rozpoczęli.

E: Ten brak publiczności, a to jest wyjątkowa siła. To napędza piłkarzy [...]. Potrzebują atencji, żeby wejść na najwyższy poziom. 
D: Holendrzy. Strzał. Van Dijk przy piłce. Niecelnie.

E: Bez publiczności nie ma widowiska. Mecz traci jakieś 50 procent. Dobrze, że dziś choć część kibiców mogła zasiąść na trybunach. A gdzie ten znany w całym świecie doping kibiców Biało-Czerwonych? Nie ma mocy. Na szczęście nasi piłkarze nie są zmanierowani.

D: Grosicki przy piłce, ale pędzi na drugi koniec boiska. Piłka uciekła mu poza linię końcową.

E: Miejmy nadzieję, że wkrótce kibice będą mogli wrócić na stadiony (TVP1, 4.09.2020).

We wszystkich trzech przykładach relacja prowadzona jest dwutorowo. Każdy z interlokutorów rozwija swój wątek i konsekwentnie, nie zważając na słowa współkomentatora, podąża za nim aż do wyczerpania tematu, zamknięcia myśli przewodniej. Występuje tu przemienność ról nadawczo-odbiorczych, jednak trudno wypowiedzi te nazwać dialogiem ze względu na brak jakichkolwiek wskaźników spójności (poza makrotematem). Można zadać pytanie o powód prowadzenia takich „równoległych monologów”, więcej - czy nie zakłócają one odbiorcy medialnemu percepcji całego przekazu, a w konsekwencji - czy duety komentatorskie spełniają swoje zadanie. Trzeba jednak pamiętać, że mamy do czynienia z tekstem stowarzyszonym z obrazem i to właśnie obraz $w$ transmisji wydarzenia sportowego jest najważniejszy. Równoczesne prowadzenie dwóch odrębnych wypowiedzi wynika z odmiennych funkcji pełnionych przez dziennikarza i eksperta. Ten pierwszy powinien koncentrować się na wydarzeniu sportowym, informować o bieżącej sytuacji meczowej itp., drugi zaś ma większą swobodę - może pozwolić sobie na rozbudowane komentarze czy dłuższe, często przygotowane przed transmisją, wypowiedzi okołomeczowe. W czasie jego wypowiedzi na arenie sportowej cały czas rozgrywa się mecz, trwa spotkanie, które relacjonuje dziennikarz. Zdarza się jednak i tak, że obaj komentujący prowadzą równoległe monologi dotyczące nie tyle samego wydarzenia sportowego, ile danej dyscypliny, zawodnika, a nawet bieżącej sytuacji $w$ świecie. Poniżej ponownie zaprezentowano fragment wymiany dziennikarsko-eksperckiej - tym razem z meczu piłki ręcznej:

D: Fernis po dwóch atakach leży.

E: Brawo, brawo, brawo Weronika. Świetny występ.

D: To jakiś bardziej poważny kłopot, jeśli chodzi o reprezentantkę Szwecji [...]. Szwedki raczej nie narzekają na kontuzje. To silne zawodniczki. Na całym świecie znana jest szwedzka szkoła przygotowania wytrzymałościowego. Byłem kiedyś na zgrupowaniu Szwedek. Bardzo dużo treningu wytrzymałościowego, siłowego. E: Trudny to czas dla sportowców i dla zwykłych ludzi. Panująca epidemia koronawirusa powoduje, że nie wie nikt, kiedy nas to spotka. Nie wiemy, czy rozegramy kolejny mecz. Trzeba cieszyć się tymi chwilami gry. Bo i zawodniczki, i kibice są stęsknieni (TVP Sport, 3.10.2020).

W zaprezentowanych przykładach „monologów równoległych” znalazły się także fragmenty transmisji komentowanych przez duety dziennikarsko-dziennikarskie. Mimo pozornego pełnienia przez obu interlokutorów tej samej funkcji, wchodzą oni w odmienne role, 
tj. jeden jest dziennikarzem, a drugi wciela się $w$ rolę eksperta. Co ciekawe, nie są to zadania przypisane na stałe do danej transmisji. W sposób płynny i dość naturalny następuje zmiana roli nie tylko $w$ zakresie nadawczo-odbiorczym, ale także pełnionej funkcji. W tym miejscu pojawia się refleksja, dlaczego niektóre stacje decydują się na takie rozwiązanie, tj. dlaczego nie pozostały przy schemacie dziennikarz-ekspert. Formuła ta występuje między innymi w kanałach tematycznych (sportowych), takich jak Eurosport i Eleven Sports. Początkowo ten swoisty eksperyment komentatorski spotykał się z krytyką, jednak okazało się, że także ta formuła znalazła swoich odbiorców. Patryk Mirosławski, szef działu sportowego Eleven, $w$ taki sposób skomentował obecność duetów dziennikarskich na antenie:

Część kibiców do dziś mnie krytykuje, że mało jest u nas tak zwanych ekspertów, czyli byłych piłkarzy i dużych dziennikarskich nazwisk. A my świadomie wybraliśmy inną drogę. Postawiliśmy na młodych, częściowo zupełnie nieznanych i bez doświadczenia telewizyjnego, co było sporym ryzykiem, ale wiedzieliśmy, że to są ludzie z pasją, którzy będą szanowali widza, którzy nigdy nie wejdą do kabiny lub studia telewizyjnego z pustą kartką. Krótko mówiąc, wiedzieliśmy, że nie będą opowiadać głupot ${ }^{3}$.

Bez wątpienia wypowiedź przedstawiciela mediów ma charakter ocenny, deprecjonujący ekspertów. Jednak przywołane analizy pokazują, że schemat przebiegu prowadzonego dialogu nie zależy od tego, kto zasiada przed mikrofonem. Nadrzędna w wielu przypadkach staje się potrzeba wypowiedzi jako takiej, często bez zwracania uwagi na wypowiedź (pozornego) interlokutora. Z braku zachowania form dialogicznych nie należy czynić jednak zarzutu. To raczej nowy sposób funkcjonowania jednoczesnych wypowiedzi dwóch osób w przestrzeni medialnej. Użyte na nazwanie tego zjawiska określenie „monolog równoległy” nie oddaje $w$ pełni jego istoty, ale wskazuje na autonomiczność wypowiedzi, co uznać należy za najważniejszą cechę monologu jako takiego. Trzeba również pamiętać o istnieniu „klasycznych partii dialogowych”, co więcej - część z nich coraz częściej przypomina rozmowy potoczne, familiarne:

D1: Po co faul w takim miejscu?

D2: Ja Ci powiem po co, Lewandowski wychodził na pozycję.

D1: Ale żeby od razu kuku robić.

D2: Podźwignął się, więc nie jest źle (Eleven Sport, 4.10.2020).

D: Dają chłopaki czadu, nieźle, nieźle się to zaczyna.

E: Meczycho jak trzeba.

D: Może trzeba było najpierw rozkminić jakąś Finlandię (TVP1, 6.10.2020).

D: Popatrz, co się dzieje.

E: Ojojoj.

3 Patryk Mirosławski: Parę razy uciekałem z klatki. Do dziś uważam, że mecz w dniu śmierci Kurmańskiego był skandalem [online: https://sportowefakty.wp.pl/zuzel/755196/patryk-miroslawski-pare-razy-uciekalem-z-klatki-do-dzis-uwazam-ze-mecz-dzien-po-; data dostępu: 8.10.2020]. 
D: Mamy remis.

E: Wow, świetnie, dziewczyny brać się do roboty i wygrać to.

D: Brawo, jest, jest punkt dla nas.

E: Brawooooo!!! (Polsat Sport, 6.10.2020).

Analizowane przykłady pokazują specyfikę sytuacji dialogowej współtworzącej telewizyjną transmisję sportową. Duety komentatorskie albo prowadzą profesjonalny dialog relacjonująco-komentatorski, albo ich wymiany przypominają reakcje rozemocjonowanych kibiców, albo pojawia się „monolog równoległy”. Poza tym możemy spotkać, co nie dziwi, bezpośrednie zwroty do telewidza, czyli niewidocznego, choć dziś coraz częściej współuczestniczącego $w$ transmisji odbiorcy medialnego, ale także wypowiedzi kierowane do zawodników (jak w ostatnim zaprezentowanym przykładzie), trenerów lub sędziów:

D: Panie sędzio, zostaw im tę piłkę, niech grają (TVP1, 6.10.2020).

Te różne konfiguracje komunikacyjne sprawiają, że mimo fizycznej obecności dwóch osób komentujących trudno mówić o dialogu jako jedynej formie podawczej.

Warto wspomnieć o jeszcze dwóch interesujących aspektach dialogu $w$ świetle widowisk sportowych jako takich. Otóż elementem, do którego często odnoszą się komentatorzy, są reakcje kibiców zasiadających na trybunach. Tymczasem epidemia koronawirusa spowodowała, że wiele spotkań odbywa się bez udziału publiczności bądź z jej bardzo ograniczoną obecnością. Jednak telewizja jako medium audiowizualne potrzebuje zarówno wizji, jak i fonii, dlatego bardzo często transmisji towarzyszą nagrane odgłosy stadionu. Ten specyficzny dialog prowadzony $w$ obrębie obiektu sportowego między kibicami a zawodnikami stanowi tak istotny element widowiska, że realizatorzy transmisji odpowiednio wzmacniają i wyciszają „odgłosy trybun”, komentujący zaś, co pokazały przytoczone przykłady, odwołują się do braku/obecności kibiców. Publiczność stadionowa, nawet ta „zbudowana z efektów specjalnych", współtworzy zatem komentarz, pomaga kształtować wspólnotę i wzmaga wrażenie bycia razem, pełniąc $w$ ten sposób funkcję fatyczną. Oczywiście, komentatorzy nie prowadzą z widzami ani na stadionie, ani przed telewizorami dialogu bezpośredniego związanego ze wspominaną wielokrotnie wymianą ról nadawczo-odbiorczych.

Analiza dialogu telewizyjnego, a za taki należy uznać zaprezentowany tu typ wymian, kierując się medium, w którym występuje, łączy się z dość złożoną sytuacją komunikacyjną. Sam dialog komentujący wpisuje się $w$ kontekst makrosytuacji komunikacyjnej właściwej dla telewizji, w której odbiorcą docelowym staje się widz. Zdaniem Justyny Winiarskiej dialog telewizyjny różni się od naturalnego brakiem partnerstwa między dziennikarzem i jego rozmówcą (WinıARSKA, 2001: 15). Tymczasem analizy pokazały, że w przypadku telewizyjnych transmisji sportowych mamy do czynienia z partnerstwem uczestników wymiany, choć nie zawsze przejawia się ono w oczywisty sposób. Często przekształca się $w$ indywidualną narrację, która jednak nie oznacza deprecjonowania współkomentującego, raczej wzmocnienie rangi komentarza jako takiego.

We wstępie do artykułu wspomniano między innymi o tym, że wprowadzenie duetów komentujących służy przede wszystkim uatrakcyjnieniu przekazu. Obserwacje poczynione na przestrzeni lat pokazują, że widzom znudził się „klasyczny” model komentarza jedno- 
osobowego. Z czasem na atrakcyjności straciła również prosta rozmowa $w$ formie dialogu, dlatego coraz częściej komentujący tworzą niezależne od siebie wypowiedzi, nadal wymieniając się rolami nadawczo-odbiorczymi. Jednym słowem, widowisko, jakim jest telewizyjna transmisja sportowa, rozpisane zostało na role, jednak te nie są sztywno przypisane dziennikarzom/ekspertom, a całe przedstawienie opisywane jest za pomocą partii dialogowych, ze znaczącym udziałem monologów równoległych.

\section{Źródła}

Mecz piłki nożnej Bayern Monachium - Hertha Berlin, komentarz: Patryk Mirosławski, Tomasz Zieliński, Eleven Sports, 4.10.2020.

Mecz piłki nożnej Holandia - Polska, komentarz: Dariusz Szpakowski, Andrzej Juskowiak, TVP1, 4.09.2020.

Mecz piłki nożnej Lazio Rzym - Inter Mediolan, komentarz: Mateusz Święcicki, Mikołaj Kruk, Eleven Sports, 4.10.2020.

Mecz piłki nożnej Polska - Finlandia, komentarz: Mateusz Borek, Robert Podoliński, TVP1, 7.10.2020.

Mecz piłki ręcznej Polska - Szwecja, komentarz: Maciej Iwański, Iwona Niedźwiedź, TVP Sport, 6.10.2020.

Mecz piłki siatkówej kobiet ŁKS - Calcitu Volley Kamnik, komentarz: Adrian Brzozowski, Milena Sadurek, Polsat Sport, 6.10.2020.

Mecz snookera Aaron Hill - Ronnie O'Sullivan, komentarz: Michał Ebert, Grzegorz Biernadski, Eurosport, 24.09.2020.

\section{Literatura}

Grochala B., 2012: Dwugłos dziennikarsko-ekspercki - wpływ czynników pragmatycznych na sposób konstruowania komentarza sportowego/relacji sportowej na żywo. „Język a Kultura”, XXIII, S. 199-209.

Grochala B., 2016: Telewizyjna transmisja sportowa w ujęciu genologii lingwistycznej (na materiale transmisji meczów piłki nożnej). Wydawnictwo Uniwersytetu Łódzkiego. Łódź.

HAGÈGE C., 1985: L'homme de parole. Contribution linguistique аия sciences humanines. Fayard. Paris. JACHıмоWSKA K., 2005: Tekst jako element komunikatu telewizyjnego (na materiale programów publicystycznych). Wydawnictwo Uniwersytetu Łódzkiego. Łódź.

KıтA M., 2004: Medialna moda na dialog. W: KıтA M., red.: Dialog a nowe media. Wydawnictwo Uniwersytetu Śląskiego. Katowice, s. 171-188.

Ligara B., Rusowicz A., 1979: Dialog telewizyjny. Próba typologii. „Zeszyty Prasoznawcze”, nr 3, S. $21-34$.

Loewe I., 2013: Dyskurs telewizyjny. W: Malinowska E., Nocoń J., Żydek-BednarczuK U., red.: Style współczesnej polszczyzny. Przewodnik po stylistyce polskiej. Universitas. Kraków, s. $289-311$.

LoEWE I., 2018: Dyskurs telewizyjny w świetle lingwistyki mediów. Wydawnictwo Uniwersytetu Śląskiego. Katowice.

MuкAŘovskı J., 1970: Wśród znaków i struktur. Państwowy Instytut Wydawniczy. Warszawa.

Ostrowskı A., 2007: Telewizyjna transmisja sportowa, czyli największy teatr świata, Wydawnictwo Naukowe Dolnośląskiej Szkoły Wyższej Edukacji TWP we Wrocławiu. Wrocław. 
OżDżYŃSKı J., 1979: Mówione warianty wypowiedzi w środowisku sportowym. Zakład Narodowy im. Ossolińskich. Wrocław.

SKUDRzyKowA A., URBAN K., 2000: Mały słownik terminów z zakresu socjolingwistyki i pragmatyki językowej. Spółka Wydawniczo-Księgarska, sp. z o.o. Warszawa.

SoвсzAк B., 2018: Retoryka telewizji. Wydawnictwo Naukowe UAM. Poznań.

Szkudlarek-Śmiechowicz E., 2010: Tekst $w$ radiowej i telewizyjnej debacie politycznej. Struktura, spójność, funkcjonalność. Wydawnictwo Uniwersytetu Łódzkiego. Łódź.

Warchala J., 1991: Dialog potoczny a tekst. Wydawnictwo Uniwersytetu Śląskiego. Katowice.

WiniARSKA J., 2001: Operatory metatekstowe $w$ dialogu telewizyjnym. Universitas. Kraków. 